\title{
NGHIÊN CỬU XÁC ĐỊNH CÁC ĐỢT LẠNH BẤT THƯỜNG TRONG CÁC THÁNG CHÍNH ĐÔNG TRÊN KHU VỰC BẮC BỘ TRONG GIAI ĐOẠN 1979-2017
}

\author{
Võ Văn Hòa1, Vũ Anh Tuấn ${ }^{2}$, Nguyễn Văn Khiêm³ \\ Nguyễn Thị Thanh Hoài ${ }^{4}$, Nguyễn Vĩnh $\mathrm{An}^{5}$
}

Tóm tắt: Bài báo này trình bày kết quả xác định các đợt lạnh bất thương trong mùa đông trên khu vực miền núi phía Bắc Việt Nam trong giai đoạn 1979-2017. Đợt lạnh bất thwờng ở đây được hiểu là một đọt rét đậm hoặc rét hại nhung có mưc độ giảm nhiệt sâu và tạo ra các giá trị nhiệt độ tối thấp ngày mang tính cực trị và hiếm gặp so với chuỗi số liệu nhiều năm. Các kết quả thống kê đã cho thấy trong giai đoạn 1979-2017 đã có 47 đợt lạnh bất thương xảy ra trong các tháng chính đông. Mùa đông có số đọt lạnh bất thuờng nhiều nhất là mùa đông 2013-2014 (5 đợt). Đọt lạnh bất thường kéo dài nhất được ghi nhất là 15 ngày (tù 21/1/1984-4/2/1984). Trong thời gian xảy ra các đọt lạnh bất thương, giá trị nhiệt độ tối thấp ngày trung bình phổ biến tù̀ 7-10 ${ }^{\circ}$. Tuy nhiên, tại nhiều điểm trạm đã ghi nhận được nhiệt độ tối thấp ngày duới $0^{\circ} \mathrm{C}$, đặc biệt là đã xảy ra hiện tuợng tuyết rơi.

Từ khóa: Đọt lạnh bất thường, mùa đông, vùng núi phía bắc.

Ban Biên tập nhận bài: 08/04/2019 Ngày phản biện xong: 18/6/2019 Ngày đăng bài: 25/06/2019

\section{Mở đầu}

Không khí lạnh (KKL) là một loại hình thời tiết nguy hiểm với tần suất xuất hiện nhiều ở Bắc Bộ Việt Nam. Theo số liệu trung bình khí hậu, hàng năm có khoảng 28-30 đợt KKL xâm nhập xuống nước ta. Mỗi đợt KKL khi xâm nhập hoặc ảnh hưởng đến nước ta thường gây ra biến đổi thời tiết mạnh mẽ: gió mạnh trên đất liền và trên biển, mưa lớn trên diện rộng và có thể có dông mạnh kèm theo gió giật mạnh. Đặc biệt vào các tháng chuyển tiếp từ mùa nóng sang mùa lạnh và ngược lại từ mùa lạnh sang mùa nóng khi KKL ảnh hưởng thường gây ra thời tiết đặc biệt nguy hiểm như dông mạnh, lốc xoáy, gió giật mạnh,... Các đợt KKL xảy ra vào các tháng chính đông thường gây ra các đợt rét đậm (nhiệt độ trung bình ngày xuống dưới $15^{\circ} \mathrm{C}$ ), rét hại (nhiệt độ trung bình ngày xuống dưới $13^{\circ} \mathrm{C}$ ) trên diện rộng và kéo dài, băng giá, sương muối trên khu vực vùng núi rất nguy hại với sức khỏe con người, cây trồng cũng như vật nuôi.

Dưới tác động của biến đổi khí hậu nên điều kiện thời tiết và khí hậu ở khu vực Bắc Bộ có chiều hướng diễn biến ngày càng phức tạp, đặc biệt là hiện tượng thời tiết có liên quan đến hoạt động của KKL. Biểu diện rõ nhất chính là xu thế gia tăng của các yếu tố và hiện tượng thời tiết, khí hậu cực trị. Phan Văn Tân và cộng sự (2010) [1] đã chỉ ra rằng số ngày rét đậm, rét hại ở Bắc Bộ có xu hướng gia tăng, nhiệt độ trung bình ngày và nhiệt độ tối thấp ngày có xu hướng giảm về phía các cực trị thấp, làm tăng mức độ nguy hiểm của các đợt rét đậm, rét hại. Các kết quả tương tự cũng được chỉ ra trong nghiên cứu của

${ }^{1}$ Đài Khi tượng Thủy văn khu vục đồng bằng Bắc bộ

${ }^{2}$ Trung tâm Dư báo Khi tương Thủy văn quốc gia

${ }^{3}$ Văn phòng Bộ Công an

${ }^{4}$ Viện Khoa học Khí tượng Thủy văn và Biến đổi khi hậu

${ }^{5}$ Truoòng Đại học Tài nguyên và môi truò̀ng Thành phố Hồ Chí Minh

Email:vovanhoa80@yahoo.com 
Đỗ Huy Dương (2013) [2], Cheong và cộng sự (2018) [3] ,... Cụ thể, do hoạt động mạnh của áp cao lục địa (giá trị khí áp tại trung tâm của áp cao lục địa đạt tới $1084 \mathrm{mb}$ ), từ ngày 23 28/2/2016 đã xảy ra ra rét đậm, rét hại diện rộng ở các tỉnh vùng núi phía Bắc. Đợt rét đậm, rét hại này tuy không kéo dài nhưng nền nhiệt độ lại giảm xuống thấp đến mức kỷ lục trong chuỗi sỗ liệu quan trắc được cho đến thời điểm xảy ra. Nhiệt độ thấp nhất tại Mẫu Sơn (Lạng Sơn) là $5,0^{\circ} \mathrm{C} ; \mathrm{Sa} \mathrm{Pa}$ (Lào Cai) là $-4,0^{\circ} \mathrm{C}$. Mưa tuyết và băng giá đã xảy ra trên diện rộng trên hầu khắp các khu vực vùng núi Bắc Bộ. Thậm chí ngay tại vườn quốc gia $\mathrm{Ba}$ Vì (Hà Nội) cũng quan sát thấy mưa tuyết là điều chưa từng xảy ra trong lịch sử (Hình 1).

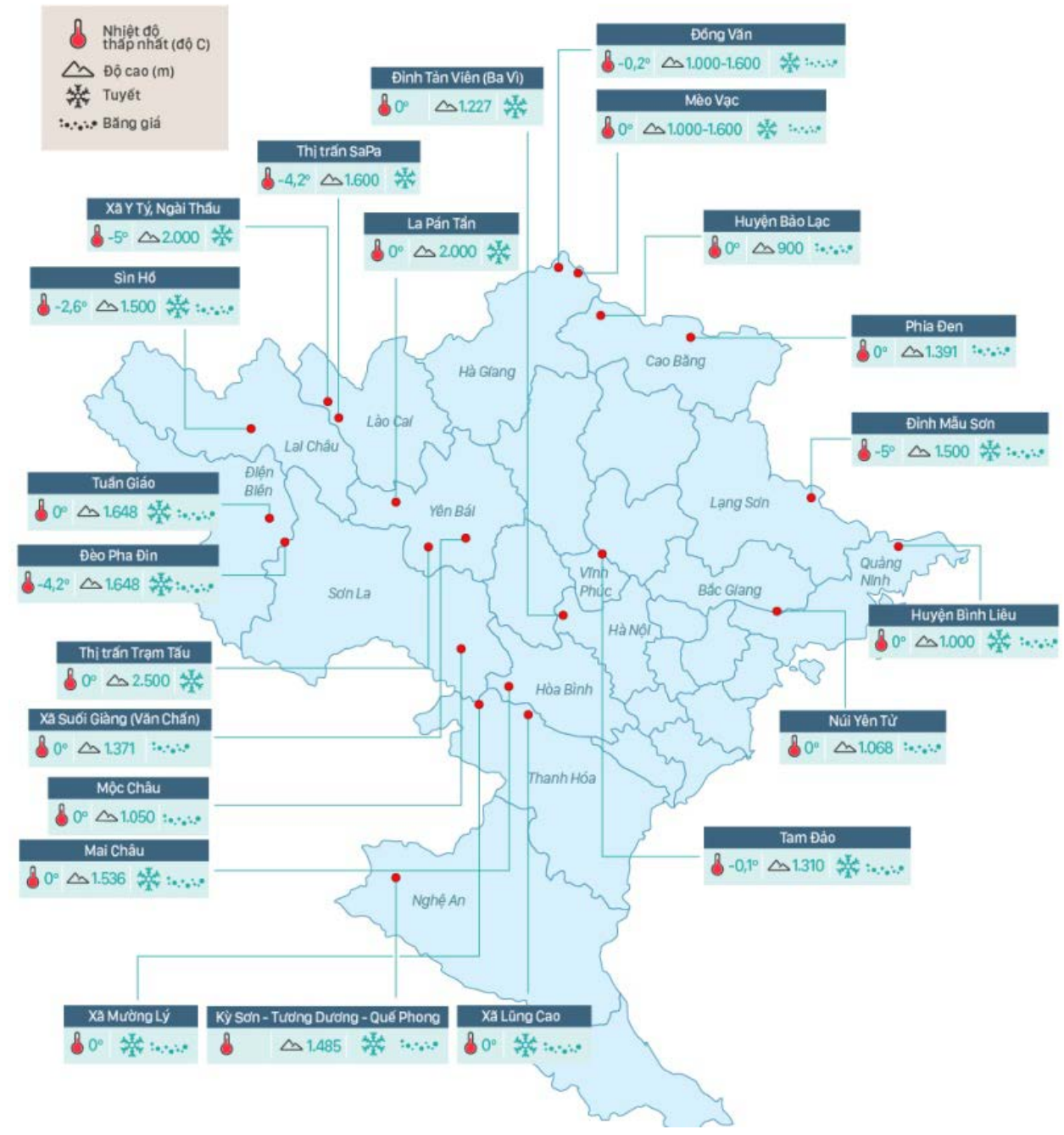

Hình 1. Thống kê mura tuyết và băng giá xảy ra diện rộng tù̀ 23-28/2/2016 ở các tỉnh Bắc Bộ do ảnh hương của $K K L$

Tương tự, đợt lạnh kỷ lục từ ngày 22 đến 27 tháng 1 năm 2016 đã khiến Bắc Bộ và Bắc Trung Bộ trải qua những ngày rét khốc liệt, nhiều nơi vùng núi cao từ 800 mét trở lên xuất hiện băng giá và mưa tuyết trong đêm 23 , ngày 24 và ngày 25/1. Theo báo cáo nhanh của Văn phòng thường trực Ban Chỉ đạo Trung ương về phòng, chống thiên tai, các địa phương bị thiệt hại nặng nhất là:
Lào Cai, Lai Châu, Yên Bái, Sơn La, Điện Biên, Cao Bằng, Lạng Sơn, Quảng Ninh, Hòa Bình, Bắc Giang, Bắc Kạn. Theo Cục Chăn nuôi, Bộ Nông nghiệp và Phát triển Nông thôn, toàn miền Bắc có gần 4.000 con gia súc bị chết rét; trong đó, có khoảng 3.200 con trâu, bò. Đã có gần 4.500 ha hoa màu và hơn 200 ha cây công nghiệp ngắn ngày bị thiệt hại; hơn 150.000 ha 
rừng của tỉnh Lào Cai bị tuyết che phủ. Tại các xã khu 2 huyện Mù Cang Chải (Yên Bái), mưa tuyết đã vùi lấp toàn bộ diện tích hoa màu của nhân dân.

Có thể thấy những đợt lạnh bất thường (hoặc cực trị) đang có xu hướng gia tăng trong những năm trở lại đây, gây ra nhiều thiệt hại cho khu vực Bắc Bộ và tạo ra nhiều thách thức cho công tác dự báo. Với phương pháp dự báo hiện tại, việc dự báo, cảnh báo kịp thời và đủ độ tin cậy hiện tượng này vẫn còn nhiều hạn chế do chưa có đủ hiểu biết về đặc điểm hoạt động, cơ chế hình thành của các đợt lạnh bất thường trên khu vực Bắc Bộ. Bài báo này sẽ chỉ tập trung vào trình bày về phương pháp luận để đưa ra các chỉ tiêu xác định "đợt lạnh bất thường" dựa trên các đặc trưng nhiệt độ và kết quả thống kê các đợt lạnh bất thường trong giai đoạn 1979-2017 dưa trên các chỉ tiêu đưa ra. Các phần tiếp theo sẽ mô tả chi tiết về tập số liệu nghiên cứu, các chỉ tiêu xác định đợt lạnh bất thường và kết quả thống kê số đợt lạnh bất thường trong giai đoạn 1979-2017.

2. Tập số liệu và phương pháp nghiên cứu 2.1. Tập số liệu nghiên cúu

Để thống kê được số đợt lạnh bất thường, các nguồn số liệu cần thiết được thu thập để phục vụ nghiên cứu gồm:

- Số liệu quan trắc nhiệt độ tối thấp ngày, nhiệt độ trung bình ngày của 66 trạm quan trắc khí tượng bề mặt thuộc các khu vực Tây Bắc, Việt Bắc, Đông Bắc và đồng bằng Bắc Bộ từ 1979-2017. Chi tiết về thông tin của các trạm có thể tham khảo trong nghiên cứu của Phan Văn Tân và cộng sự (2010) [1].

- Số liệu chuẩn sai nhiệt độ trung bình ngày trong các tháng chính đông $(12,1$ và 2$)$ của 66 trạm quan trắc khí tượng bề mặt nói trên.

- Kết quả thống kê các đợt KKL (gồm gió mùa đông bắc và KKL tăng cường) trong giai đoạn 1979-2017 của Trung tâm Dự báo KTTV quốc gia.

2.2. Xây dụng bộ chỉ tiêu xác định đột lạnh bất thường

Đợt lạnh bất thường trong nghiên cứu này được hiểu là một đợt rét đậm hoặc rét hại nhưng có mức độ giảm nhiệt sâu (so với độ lệch chuẩn của nhiệt độ trung bình tháng) và có giá trị nhiệt độ tối thấp ngày mang tính cực trị rất thấp và hiếm gặp so với chuỗi số liệu nhiều năm. Như vậy, có thể thấy tiêu chuẩn đầu tiên khi xem xét một đợt lạnh bất thường chính là phải thỏa mãn tiêu chí của một đợt rét đậm hoặc rét hại.

Dựa trên số liệu thống kê đã biết về các đợt KKL trong giai đoạn 1979-2017, các phân tích chi tiết về cơ chế hoàn lưu chi phối, các đặc trưng nhiệt, ẩm, gió và mưa trong thời gian xảy ra, các hệ quả thời tiết đi kèm, ... được thực hiện cho từng đợt. Sau đó, các kết quả phân tích này được tổng hợp để tìm ra các đặc điểm chung mang tính phổ biến và đặc điểm riêng mang tính sự kiến hiếm. Các đặc điểm riêng tiếp tục được đưa vào phân tích theo các khía cạnh không gian, thời gian, cường độ và chế độ hoàn lưu để xác định xem có phải là bất thường hay không. Từ các kết quả nhận được, bộ chỉ tiêu ban đầu sẽ được đề xuất và áp dụng ngược trở lại bộ số liệu đã qua để thống kê số đợt lạnh bất thường. Các kết quả thống kê nhận được tiếp tục được phân tích để kiểm chứng và điều chỉnh lại bộ chỉ tiêu.

Theo định nghĩa về một đợt rét đậm, rét hại thì một khu vực dự báo được coi là có rét đậm, rét hại trên diện rộng khi rét đậm, rét hại xảy ra ở quá một nửa số trạm trong toàn bộ số trạm quan trắc của khu vực đó. Cụ thể, với 66 trạm quan trắc khi tượng bề mặt được sử dụng, thì khu vực Bắc Bộ được coi là có rét đậm, rét hại trên diện rộng khi có ít nhất 33 trạm thỏa mãn điều kiện là có xảy ra rét đậm, rét hại. Do đó, nếu xem xét khía cạnh này, thì chỉ tiêu cho một đợt lạnh bất thường xảy ra trong mùa đông theo không gian phải thỏa mãn tiêu chí khắt khe hơn so với các tiêu chí đã kể ra ở trên. Trong nghiên cứu này chúng tôi đưa ra tiêu chí: "Một đợt lạnh được coi là bất thường trong mùa đông phải là một đợt không khí lạnh gây rét đậm, rét hại trên diện rộng với $2 / 3$ số trạm trong khu vực xảy ra rét đậm, rét hại và có ít nhất $1 / 2$ số trạm trong khu vực dự báo xảy ra rét hại”.

Như đã phân tích, đợt lạnh bất thường được hiểu là đợt lạnh tạo ra sự giảm sâu của nền nhiệt 
độ trung bình ngày cũng như giá trị nhiệt độ tối thấp ngày. Do đó, chúng tôi sử dụng đặc tính này như là một tiêu chí xác định. Cụ thể, giá trị nhiệt độ trung bình tháng trong các tháng chính đông tại các trạm nghiên cứu sẽ được so sánh với chuẩn sai tháng khí hậu của nhiệt độ trung bình ngày để tìm ra tháng có mức độ giảm nhiệt bất thường so với khí hậu. Dựa trên bộ số liệu chuẩn sai tháng của nhiệt độ trung bình ngày trong các tháng chính đông trong giai đoạn 1979-2017, chúng tôi nhận thấy ngưỡng giảm $0.5^{\circ} \mathrm{C}$ là hợp lý và ngưỡng giảm nhiệt độ này được sử dụng như là một tiêu chí xác định đợt lạnh bất thường theo khía cạnh giảm nhiệt độ.

Sau khi xác định được các tháng trong mùa đông có chuẩn sai nhiệt độ trung bình tháng có giá trị $\leq-0,5^{\circ} \mathrm{C}$, cần tiếp tục lọc ra được các ngày nghi ngờ có xảy ra những đợt lạnh bất thường. Câu hỏi đặt ra là nhiệt độ trung bình ngày $\left(\mathrm{T}_{\mathrm{tb}}\right)$ hoặc nhiệt độ tối thấp ngày $\left(\mathrm{T}_{\mathrm{m}}\right)$ giảm xuống ngưỡng bao nhiêu cho từng trạm quan trắc mới được coi là bất thường?. Qua thống kê, phân tích, phân loại trong tất cả các đợt rét đậm, rét hại diện rộng xảy ra trong giai đoạn 1979-2017 cho khu vực Bắc Bộ, chúng tôi nhận thấy khi xảy ra đồng thời hoặc một trong hai tiêu chí sau đó là $\mathrm{T}_{\mathrm{tb}} \leq$ $12,0^{\circ} \mathrm{C}$ hoặc $\mathrm{T}_{\mathrm{m}} \leq 10,0^{\circ} \mathrm{C}$ thì xác suất xảy ra các đợt lạnh bất thường là rất cao. Việc sử dụng thêm cặp tiêu chính này sẽ khắc phục được việc bỏ sót các đợt lạnh bất thường do trong thực tế có những tháng chuẩn sai nhiệt độ trung bình tháng không giảm xuống dưới $-0,5^{\circ} \mathrm{C}$ nhưng vẫn xuất hiện những đợt lạnh bất thường do nhiệt độ trung bình ngày giảm sâu.

Qua xem xét, phân tích và đánh giá các đợt KKL gây rét đậm, rét hại trên diện rộng trên toàn khu vực Bắc Bộ trong giai đoạn 1979-2017, có rất nhiều đợt có sự giảm nhanh và mạnh của nhiệt độ. Ví dụ như đợt rét đậm rét hại từ ngày 15/1/2008 và kéo dài đến hết ngày 20/2/2008 ở vùng núi và trung du Bắc Bộ đã xảy ra 31 ngày rét hại, đáng chú ý nhất là ngày $1 / 2 / 2008$ là ngày rét nhất trong đợt rét này với nhiệt độ trung bình ngày phổ biến từ $6-8^{\circ} \mathrm{C}$, một số nơi thấp hơn như: Lạng Sơn là $3,9^{\circ} \mathrm{C}$; Cao Bằng là $5,3^{\circ} \mathrm{C} ; \ldots$ Đây cũng là ngày có nhiệt độ trung bình ngày thấp nhất trong chuỗi số liệu nhiều năm. Tại Sapa nhiệt độ trung bình ngày đã xuống thấp kỷ lục $-0.1^{\circ} \mathrm{C}$ (ngày $14 / 2$ ). Trong đợt rét đậm rét hại này nhiệt độ thấp nhất tại một số nơi thuộc vùng núi cao Bắc Bộ xuống dưới $0^{\circ} \mathrm{C}$ như: $\mathrm{Sa} \mathrm{Pa}$ : $1,0^{\circ} \mathrm{C}$; Mẫu Sơn (Lạng Sơn): $-2,0^{\circ} \mathrm{C}$; vùng đồng bằng trung $\mathrm{du}$ Bắc Bộ từ $4-7^{\circ} \mathrm{C}$ (Hà Nội 6,7 $\left.{ }^{\circ} \mathrm{C}\right) ; \ldots$

Vậy đâu là nguyên nhân gây ra đợt rét đậm, rét hại khiến nhiệt độ trung bình ngày giảm xuống mức kỷ lục như vậy ?. Qua xem xét, đánh giá, phân tích các hình thế thời tiết chi phối, 2 yếu tố chính quyết định đặc tính bất thường này gồm 1) Nguồn gốc và cường độ KKL; và 2) Hoạt động của dòng xiết gió Tây trên cao. Một yếu tố nữa cũng là nguyên nhân làm giảm nhiệt mạnh trên khu vực các tỉnh miền núi phía Bắc chính là ảnh hưởng của địa hịnh núi cao trên khu vực này. Tuy nhiên, đây chỉ là yếu tố phụ và chỉ có tác dụng làm tăng thêm khả năng giảm nhiệt độ khí có tác động của KKL nói chung.

Thông thường, trong những tháng mùa đông, KKL ảnh hưởng tới nước ta theo 3 nguồn gốc khác nhau: 1) từ trung tâm áp cao trên khu vực Siberia; 2) từ KKL cực đới từ bắc cực di chuyển xuống khu vực Siberia và 3 ) từ KKL di chuyển từ phía châu Âu đi sang bổ sung cho khối khí lạnh sẵn có trên khu vực Siberia. Trong 3 nguồn gốc trên thì nguồn gốc số 1 và số 2 là những nguồn gốc chủ đạo, gây ảnh hưởng mạnh nhất và làm giảm nhiệt độ mạnh nhất tới nước ta một khi chúng mở rộng về phía nam. Điều này một phần là do thời gian và quãng đường nó di chuyển xuống là khá ngắn, mặt khác cũng bắt nguồn từ vị trí địa lý của chúng. Còn không khí lạnh có nguồn gốc từ Châu Âu đi sang phải trải qua một quãng đường và thời gian di chuyển khá dài nên khi đến khu vực Siberia thường yếu đi và tĩnh lại ở đó đồng thời chờ đợi sự bổ sung KKL ở đây hoặc ở Bắc Cực đi xuống, khi đủ lớn chúng mới bắt đầu phát triển xuống phía nam. 


\section{BÀI BÁO KHOA HỌC}

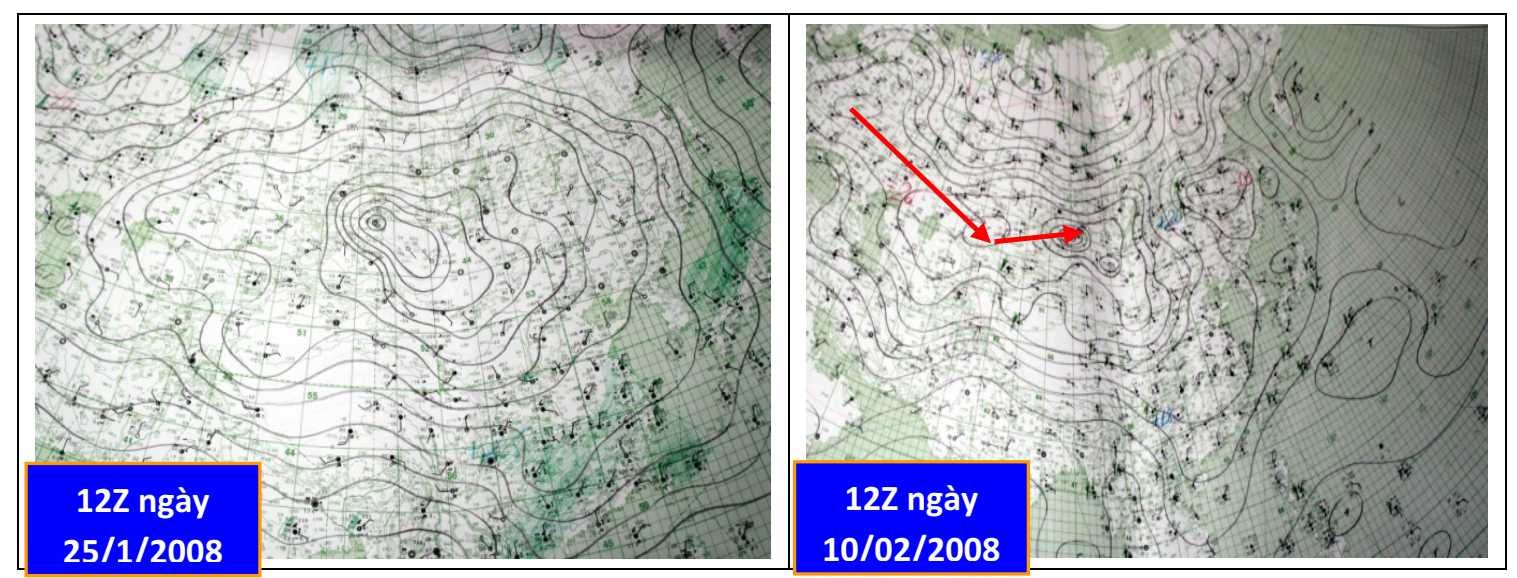

Hình 2. Bản đồ mặt đẳng áp Âu-Á lúc 19 giờ các ngày 25/1 và 10/2/2008

Hình 2 đưa ra bản đồ phân tích mặt đẳng áp Âu-Á tại thời điểm 19 giờ các ngày $25 / 1$ và 10/2/2008 mô tả nguồn gốc ảnh hưởng của khối KKL trong đợt lạnh từ $15 / 1$ và kéo dài đến hết 20/2/2008. Cho thấy hầu hết đều xuất phát từ các nguồn gốc: trung tâm áp cao trên khu vực Siberia (hình 2, bên trái), KKL cực đới từ bắc cực di chuyển xuống khu vực Siberia và KKL di chuyển từ phía châu Âu đi sang bổ sung cho KKL sẵn có trên khu vực Siberia (hình 2 , bên phải). Hình 3 tiếp tục đưa ra bản đồ phân tích mặt đẳng áp Âu-Á tại thời điểm 07 giờ các ngày 23/1 (thời điểm bắt đầu) và 28/1/2016 (thời điểm trước khi kết thúc) mô tả cường độ khối $\mathrm{KKL}$ khi ảnh hưởng đến Việt Nam trong đợt lạnh gây giảm nhiệt kỷ lục ở các tỉnh miền núi phía Bắc biệt nam từ 23 đến 28/1/2016. Giá trị khí áp trung tâm vào 2 thời điểm này cũng cho thấy đây là một khối KKL rất mạnh. Tại thời điểm 7 giờ ngày $23 / 1$, rất nhiều vị trí có trị số khí áp trung tâm vượt quá $1070 \mathrm{mb}$ và trị số lớn nhất xác định được là $1084,3 \mathrm{mb}$. Sang đến thời điểm 7 giờ ngày $28 / 1$, lúc này trị số khí áp trung tâm đã giảm đi đáng kể so với ngày 23/1 và trị số khí áp lớn nhất xác định được là 1064,2mb. Đây cũng là thời điểm đánh dấu kết lúc của đợt lạnh bất thường gây nhiệt độ giảm sâu này. Một nguyên nhân nữa cũng đóng vai trò quan trọng trong cả 2 đợt lạnh nói trên chính là hoạt động mạnh của dòng xiết gió tây trên cao gây ra mưa nhỏ, mưa phùn trên khu vực Bắc Bộ.

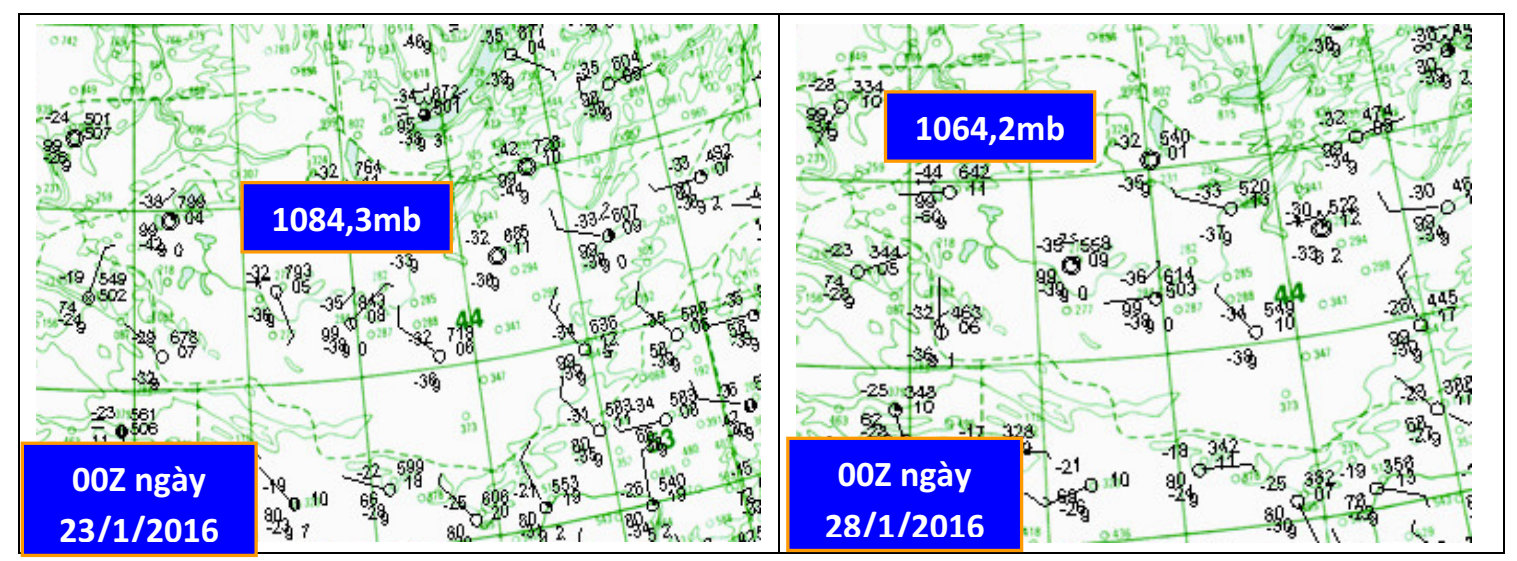

Hình 3. Bản đồ mặt đẳng áp Âu-Á lúc 07 giờ các ngày 23 và 28/1/2016 


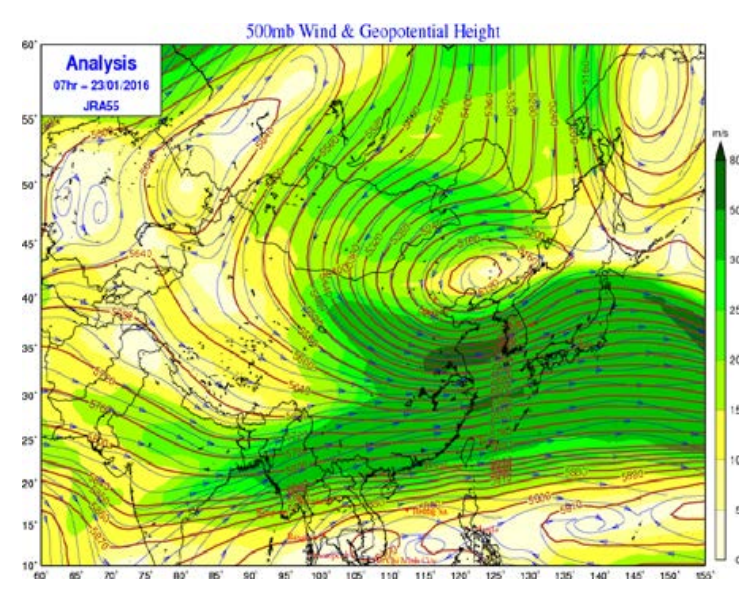

Hình 4. Bản đồ tái phân tích mục 500mb trong các ngày 23/1 và 28/1/2016

Hình 4 đưa ra bản đồ tái phân tích trường gió và độ cao địa thế vị vào thời điểm 7 giờ các ngày $23 / 1$ và $28 / 1$ năm 2016. Trên bản đồ ngày 23/1/2016 (hình 4 , bên trái) lúc này toàn bộ khu vực các tỉnh Bắc Bộ đã nằm sâu trong vùng ảnh hướng của dòng xiết hướng Tây Nam với cường độ gió là rất mạnh trên khu vực các tỉnh miền núi phía Bắc, dao động trong khoảng 30-50m/s. Mưa nhỏ mưa phùn xuất hiện nhiều ở hầu khắp các tỉnh Bắc Bộ nói chung và khu vực các tỉnh miền núi phía Bắc nói riêng. Sang ngày 28/1 (hình 4 , bên phải) toàn bộ khu vực Bắc Bộ vẫn nằm trong khu vực hội tụ gió Tây Nam trước rãnh nên mưa nhỏ tiếp tục xảy ra trong ngày $28 / 1$. Sau đó khi rãnh gió Tây lướt sang phía Đông trả lại bầu KKL sau rãnh, mưa giảm nhanh trên khu vực các Bắc Bộ và nhiệt độ có xu hướng tăng nhanh kết thúc đợt rét hại kèm theo mưa tuyết trên diện rộng này. Do đó, trong nghiên cứu này chúng tôi bổ sung thêm chỉ tiêu về hình thế đó là: 1) nguồn gốc khối không khí lạnh ảnh hưởng là trên khu vực Siberia rộng lớn và khí áp trung tâm của khối không khí lạnh phải vượt quá 1070mb; 2) Phải có hoạt động của dòng xiết gió Tây trên khu vực Bắc Bộ.

Qua các phân tích ở trên, bộ tiêu chính xác định các đợt lạnh bất thường trong các tháng chính đông trên khu vực Bắc Bộ bao gồm:

1) Phải là một đợt không khí lạnh gây rét đậm, rét hại trên diện rộng với $2 / 3$ số trạm trong khu vực xảy ra rét đậm, rét hại và có ít nhất $1 / 2$ số trạm trong khu vực dự báo xảy ra rét hại;

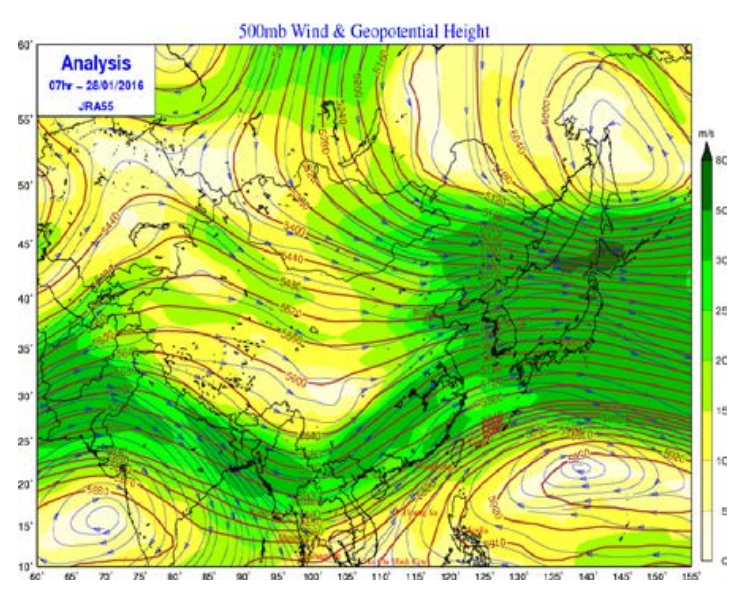

2) Có chuẩn sai tháng của nhiệt độ trung bình ngày giảm ít nhất $0.5^{\circ} \mathrm{C}$ so với giá trị trung bình nhiều năm (1986-2005);

3) Nhiệt độ trung bình ngày $\left(T_{t b}\right)$ và nhiệt độ tối thấp ngày $\left(\mathrm{T}_{\mathrm{m}}\right)$ giảm xuống đồng thời ngưỡng $\mathrm{T}_{\mathrm{tb}} \leq 12,0^{\circ} \mathrm{C}$ và $\mathrm{T}_{\mathrm{m}} \leq 10,0^{\circ} \mathrm{C}$, hoặc xảy ra một trong hai tiêu chí này;

4) Nguồn gốc khối không khí lạnh ảnh hưởng là trên khu vực Siberia rộng lớn và khí áp trung tâm của khối không khí lạnh phải vượt quá $1070 \mathrm{mb}$

5) Phải có hoạt động của dòng xiết gió Tây trên khu vực Bắc Bộ

\subsection{Qui trình xác định đợt lạnh bất thwờng}

Qui trình xác định đợt lạnh bất thường bao gồm các bước như sau:

Bước 1: Xác định các tháng có mức giảm nhiệt độ sâu so với trung bình khí hậu (sử dụng tiêu chí 2 kết hợp với tiêu chí 1).

Bước 2: Dựa trên kết quả thống kê các đợt KKL đã biết trong tháng được xác định ở bước 1 để xác định các ngày chịu ảnh hưởng của các đợt KKL

Bước 3: Xác định các ngày được tìm thấy trong Bước 2 xem có thỏa mãn tiêu chí 3 hay không (kết hợp với tiêu chí 1), nếu có thì chuyển sang bước 4.

Bước 4: Xác định xem đợt KKL đang xét có thỏa mãn tiêu chí 4 và 5 hay không. Nếu có thì đợt $\mathrm{KKL}$ này được xác định là đợt lạnh bất thường. 
3. Kết quả xác định các đọ̣t lạnh bất thường trong các tháng chính đông trên khu vực Bắc Bộ trong giai đoạn 1979-2017

Bảng 1 đưa ra kết quả xác định và thống kê các đặc trưng của các đợt lạnh bất thường trong các tháng chính đông trong giai đoạn 1979-2017 dựa trên bộ tiêu chí xác định ở trên. Cụ thể, đã có 47 đợt lạnh bất thường được xác định trong đó về tần suất trung bình có 1,2 đợt/năm. Năm có nhiều đợt xảy ra nhất là năm 2014 (có 5 đợt xảy ra). Nếu tính theo mùa đông, thì mùa đông 20132014 là mùa đông có nhiều đợt xảy ra nhất (5 đợt). Đợt lạnh bất thường kéo dài nhất được ghi nhất là 15 ngày (từ 21/1/1984-4/2/1984). Trong thời gian xảy ra các đợt lạnh bất thường, giá trị nhiệt độ tối thấp ngày trung bình phổ biến từ 5 $8^{\circ} \mathrm{C}$. Tuy nhiên, tại nhiều điểm trạm đã ghi nhận được nhiệt độ tối thấp ngày dưới $0^{\circ} \mathrm{C}$, đặc biệt là đã xảy ra hiện tượng tuyết rơi.

Bảng 1 cũng có thể thấy một đặc điểm đáng lưu ý là việc giảm sâu của nền nhiệt độ trung bình ngày trong các đợt lạnh bất thường không đồng nghĩa với sự giảm sâu của nhiệt độ tối thấp ngày. Cụ thể, nếu xem xét các đợt lạnh bất thường xảy ra trong các tháng 1 và 2 năm 1980 , tháng 1 năm 1983, tháng 2 năm 2008, tháng 1 năm 2011, thì mức độ giảm nhiệt độ trung bình ngày so với chuẩn sai tháng của nhiệt độ trung bình ngày có thể lên tới từ $-2.5^{\circ} \mathrm{C}$ đến $-4.5^{\circ} \mathrm{C}$. Tuy nhiên, nhiệt độ tối thấp ngày phổ biến chỉ xuống tới $8-10^{\circ} \mathrm{C}$. Ngược lại, các đợt lạnh bất thường trong các tháng 2 và 12 của năm 1993 , tháng 12 năm 1995, tháng 1 năm 1996 và tháng 1 năm 2016 cho thấy nhiệt độ tối thấp ngày giảm rất sâu xuống phổ biến từ $5-7^{\circ} \mathrm{C}$, nhưng mức độ giảm nền nhiệt độ trung bình ngày so với chuẩn sai tháng chỉ ở mức $-1^{\circ} \mathrm{C}$ đến $-0.5^{\circ} \mathrm{C}$. Sự giảm đồng thời chỉ được tìm thấy tại các đợt lạnh xảy ra vào tháng 12 năm 1983, tháng 12 năm 1987. Như vậy, có thể thấy còn nhiều yếu tố khác chi phối tới tính bất thường của trong trường nhiệt độ của các đợt lạnh bất thường chưa được xem xét đưa vào trong chỉ tiêu xác định.

Bảng 1. Kết quả xác định và thống kê các đặc trung của các đột lạnh bất thường trong các tháng chinh đông trong giai đoạn 1979-2017

\begin{tabular}{ccccccc}
\hline TT & Năm & Tháng & Ngày xảy ra & $\begin{array}{c}\text { Mức giảm nhiệt } \\
\text { so với chuẩn sai }\end{array}$ & $\begin{array}{c}\text { Nhiệt độ trung } \\
\text { bình ngày }\left({ }^{\circ} \mathrm{C}\right)\end{array}$ & $\begin{array}{c}\text { Nhiệt độ tối } \\
\text { thấp ngày }\left({ }^{\circ} \mathrm{C}\right)\end{array}$ \\
\hline 7 & & & $21-26$ & $-3.0 \div-2.5$ & $8-10$ & $6-8$ \\
8 & & 12 & $1-4$ & $-3.0 \div-2.5$ & $8-10$ & $5-7$ \\
9 & & $28-31$ & $-3.0 \div-2.5$ & $8-10$ & $5-7$ \\
10 & 1984 & 1 & $21 / 1-4 / 2$ & $-1.0 \div-0.5$ & $10-12$ & $8-10$ \\
11 & 12 & $20-31$ & $-3.5 \div-3.0$ & $10-12$ & $8-10$ \\
12 & 1986 & 1 & $6-9$ & $-0.5 \div-0.0$ & $10-12$ & $5-7$ \\
13 & 1987 & 12 & $6-10$ & $-3.0 \div-2.5$ & $10-12$ & $6-8$ \\
14 & & $17-19$ & $-3.0 \div-2.5$ & $10-12$ & $5-7$ \\
15 & 1988 & 2 & $10-12$ & $-1.5 \div-1.0$ & $10-12$ & $7-9$ \\
16 & 1989 & 1 & $13-16$ & $-1.5 \div-1.0$ & $10-12$ & $8-10$ \\
17 & 1990 & 2 & $1-3$ & $-1.0 \div-0.5$ & $10-12$ & $8-10$ \\
18 & 1991 & 12 & $28-30$ & $0.5 \div 1.0$ & $9-11$ & $7-9$ \\
19 & & 1 & $15-25$ & $-1.5 \div-2.0$ & $10-12$ & $8-10$ \\
20 & 1993 & 2 & $1-3$ & $0.0 \div 0.5$ & $10-12$ & $5-7$ \\
21 & & 12 & $25-29$ & $-1.0 \div-0.5$ & $10-12$ & $5-7$
\end{tabular}




\begin{tabular}{|c|c|c|c|c|c|c|}
\hline $\mathrm{TT}$ & Năm & Tháng & Ngày xảy ra & $\begin{array}{l}\text { Mức giảm nhiệt } \\
\text { so với chuẩn sai }\end{array}$ & $\begin{array}{l}\text { Nhiệt độ trung } \\
\text { bình ngày }\left({ }^{\circ} \mathrm{C}\right)\end{array}$ & $\begin{array}{l}\text { Nhiệt độ tối } \\
\text { thấp ngày }\left({ }^{\circ} \mathrm{C}\right)\end{array}$ \\
\hline 22 & 1994 & 1 & $20-22$ & $0.5 \div 1.0$ & $10-12$ & $8-10$ \\
\hline 23 & 1995 & 12 & $30-31$ & $-1.0 \div-0.5$ & $10-12$ & $5-7$ \\
\hline 24 & \multirow{2}{*}{1996} & 1 & $1-4$ & $-1.0 \div-0.5$ & $10-12$ & $5-7$ \\
\hline 25 & & 2 & $19-25$ & $-2.5 \div-2.0$ & $9-11$ & $6-8$ \\
\hline 26 & 1998 & 1 & $19-20$ & $1.5 \div 2.0$ & $10-12$ & $8-10$ \\
\hline 27 & 1999 & 12 & $23-27$ & $-2.5 \div-2.0$ & $8-10$ & $2-4$ \\
\hline 28 & 2002 & 12 & $27-29$ & $0.5 \div 1.0$ & $10-12$ & $8-10$ \\
\hline 29 & 2003 & 1 & $6-9$ & $-1.0 \div-0.5$ & $9-11$ & $8-10$ \\
\hline 30 & 2004 & 2 & $6-8$ & $-0.5 \div 0.0$ & $10-12$ & $8-10$ \\
\hline 31 & 2005 & 1 & $1-3$ & $-1.0 \div-0.5$ & $10-12$ & $7-9$ \\
\hline 32 & \multirow{2}{*}{2008} & 1 & $31 / 1-2 / 2$ & $-2.0 \div-1.0$ & $6-8$ & $5-7$ \\
\hline 33 & & 2 & $10-14$ & $-5.0 \div-4.5$ & $10-12$ & $8-10$ \\
\hline 34 & \multirow{2}{*}{2011} & \multirow{2}{*}{1} & $11-13$ & $-4.0 \div-3.5$ & $8-10$ & $6-8$ \\
\hline 35 & & & $16-21$ & $-4.0 \div-3.5$ & $9-11$ & $8-10$ \\
\hline 36 & \multirow{2}{*}{2012} & \multirow{2}{*}{1} & $4-6$ & $-2.0 \div-1.5$ & $9-11$ & $7-9$ \\
\hline 37 & & & $25-27$ & $-2.0 \div-1.5$ & $10-12$ & $8-10$ \\
\hline 38 & \multirow{2}{*}{2013} & 1 & $11-13$ & $-1.5 \div-1.0$ & $10-12$ & $9-11$ \\
\hline 39 & & 12 & $16-28$ & $-3.0 \div-2.5$ & $10-12$ & $6-8$ \\
\hline 40 & \multirow{5}{*}{2014} & \multirow{2}{*}{1} & $14-16$ & $-1.0 \div-0.5$ & $11-13$ & $6-8$ \\
\hline 41 & & & $22-24$ & $-1.0 \div-0.5$ & $11-13$ & $6-8$ \\
\hline 42 & & \multirow{2}{*}{2} & $11-13$ & $-1.0 \div-0.5$ & $9-11$ & $7-9$ \\
\hline 43 & & & $19-21$ & $-1.0 \div-0.5$ & $10-12$ & $8-10$ \\
\hline 44 & & 12 & $18-23$ & $-1.5 \div-1.0$ & $11-13$ & $7-9$ \\
\hline 45 & 2015 & 1 & $13-15$ & $0.0 \div 0.5$ & $11-13$ & $6-8$ \\
\hline 46 & \multirow{2}{*}{2016} & 1 & $24-27$ & $-0.5 \div 0.0$ & $6-8$ & $4-6$ \\
\hline 47 & & 2 & $8-9$ & $-3.0 \div-2.5$ & $12-14$ & $6-8$ \\
\hline
\end{tabular}

\section{Kết luận và kiến nghị}

tháng chính đông trên khu vực Bắc Bộ. Đợt lạnh bất thường ở đây được hiểu là một đợt rét đậm hoặc rét hại nhưng có mức độ giảm nhiệt sâu và tạo ra các giá trị nhiệt độ tối thấp ngày mang tính cực trị và hiếm gặp so với chuỗi số liệu nhiều năm. Dựa trên các kết quả phân tích về hình thế thời tiết chi phối, đặc điểm của trường nhiệt độ trung bình ngày và tối thấp ngày, bộ các tiêu chí xác định đã được đưa ra. Các tiêu chí này chủ yếu dựa trên đặc tính giảm nhiệt và hình thế thời tiết chi phối. Các kết quả thống kê đã cho thấy trong giai đoạn 1979-2017 đã có 47 đợt lạnh bất thường xảy ra trong các tháng chính đông. Mùa đông có số đợt lạnh bất thường nhiều nhất là mùa đông 2013-2014 (5 đợt). Đợt lạnh bất thường kéo dài nhất được ghi nhất là 15 ngày (từ 21/1/1984-4/2/1984). Trong thời gian xảy ra các đợt lạnh bất thường, giá trị nhiệt độ tối thấp ngày trung bình phổ biến từ $7-10^{\circ} \mathrm{C}$. Tuy nhiên, có nhiều đợt lạnh bất thường nhiệt độ tối thấp có thể phổ biến từ $5-7^{\circ} \mathrm{C}$ trên toàn bộ khu vực nghiên cứu. Đặc biệt, trong đợt lạnh bất thường từ 24-27 tháng 1 năm 2016, có tại nhiều điểm 


\section{BÀI BÁO KHOA HỌC}

trạm đã ghi nhận được nhiệt độ tối thấp ngày dưới $0^{\circ} \mathrm{C}$, đặc biệt là đã xảy ra hiện tượng tuyết rơi.

Các kết quả thống kê cũng cho thấy bộ tiêu chí đưa ra vẫn còn một số hạn chế như chưa giải thích được quan hệ đồng pha trong mức độ giảm nền nhiệt độ trung bình ngày với nhiệt độ tối thấp ngày. Do đó, việc điều chỉnh lại ngưỡng xác định dựa trên các nhân tố này có thể làm thay đổi đáng kể kết quả thống kê. Trong nghiên cứu tiếp theo, chúng tôi sẽ tập trung giải quyết bật cập này để điều chỉnh lại bộ chỉ tiêu, đồng thời tiếp tục nghiên cứu sau hơn để giải thích cơ chế và nguyên nhân hình thành các đợt lạnh bất thường trong các tháng chính đông trên khu vực Bắc Bộ.

Lời cảm ơn: Các tác giả xin gửi lời cảm on tới đề tài NCKH cấp Nhà nước "Nghiên cưu tác động của biến đổi khí hậu tới sự xâm nhập của các đợt lạnh và nóng ấm bất thường trong mùa đông ở khu vực miền núi phía Bắc phục vu phát triển kinh tế - xã hội”, mã số BĐKH.25/16-20 đã hỗ trợ để nhóm thực hiện nghiên cúu này. Bài báo này cũng là kết quả thực hiện của một nội dung trong đề tài nói trên.

\section{Tài liệu tham khảo}

1. Phan Văn Tân và cộng sự, (2010), Nghiên cứu tác động của biến đổi khí hậu toàn cầu đến các yếu tố và hiện tượng khi hậu cực đoan ở Việt Nam, khả năng dụ báo và giải pháp chiến lược ứng phó. Báo cáo Tổng kết Đề tài KHCN cấp Nhà nước, mã số KC08.29/06-10.

2. Đỗ Huy Dương (2013), Nghiên cưu mô phỏng một số yếu tố và hiện tượng khi hậu cực đoan bằng mô hình khí hậu khu vực. Luận án tiến sĩ ngành khí hậu học, 185 tr.

3. Cheong, W.K., Timbal, B., Golding, N., Sirabaha, S., Kwan, K.F., Cinco, T.A., Archevarahuprok, B., Vo, V.H., Gunawan, D., Han, S. (2018), Observed and modelled temperature and precipitation extremes over Southeast Asia from 1972-2010. International Journal of Climatology, 38, 3013-3027. 


\title{
STUDY ON ABNORMAL COLD SPELL IN THE MID-WINTER IN THE NORTHERN PART OF VIET NAM DURING 1979-2017 \\ Vo Van Hoa', Vu Anh Tuan², Nguyen Van Khiem ${ }^{3}$, Nguyen Thi Thanh Hoai ${ }^{4}$, Nguyen Vinh $\mathbf{A n}^{5}$ \\ ${ }^{1}$ Red-river Delta Regional Hydro-Meteorological Center \\ ${ }^{2}$ National Center for Hydro-Meteorological Forecasting \\ ${ }^{3}$ Ministry of Public Security Office \\ ${ }^{4}$ Viet Nam Institude of Meteorology, Hydrology and Climate Change \\ ${ }^{5}$ Hochiminh City University of Natural Resources and Environment
}

\begin{abstract}
This paper presents the results of researching abnormal cold spells in mid-winter in the Northern part of Vietnam during 1979-2017. The abnormal cold spell is a severe or damaging cold spell, and it contributes greatly to a significant reduction of daily average temperature and extreme daily minimum temperature values that are unique compared to the data for many years. The statistical results showed that during the period 1979-2017, there were 47 unusual cold spells during the mid-winter months. The winter with the highest number of unusual cold spells was the winter of 2013-2014 (5 cold waves). The longest abnormally cold spell was recorded for 15 days (from January 21, 1984 to February 4, 1984). During periods of unusual cold spells, the average daily minimum temperature value was between $7-10^{\circ} \mathrm{C}$. However, at many points the station recorded the daily low temperature below $0^{\circ} \mathrm{C}$, especially the phenomenon of snowfall (extremely rare event).
\end{abstract}

Keywords: Abnormal cold spell, Northern part of Vietnam. 